\title{
WHAT MAKES THE CYBERBULLYING MODEL AMONG VOCATIONAL HIGH SCHOOL STUDENTS
}

\author{
Naila Nasywa, Fatwa Tentama*, Mujidin \\ Universitas Ahmad Dahlan, Indonesia \\ *e-mail: fatwa.tentama@psy.uad.ac.id
}

\begin{abstract}
Cyberbullying refers to aggressive behaviors in social media in the forms of repeated actions of insults, shaming, and threats to other people. This study aims to examine the model of empathy, selfesteem, and school climate effects on cyberbullying to vocational students. The participants of this study were 505 eleventh grade students from vocational schools X, Y, and Z in Yogyakarta. The sample of this study included 180 students which were selected from the population using the cluster random sampling technique. Data were collected using the empathy, self-esteem, and school environment scales. The collected data were then analyzed using inner and outer model tests in Structural Equation Model (SEM) using Smart Partial Least Square 3.2.8. The results of this study show that the model with empathy, selfesteem, and school climate to predict cyberbullying had a good fit with the empirical data. It was found that empathy and school environment had a negative effect on cyberbullying. In contrast, no effects were found in self-esteem and cyberbullying.
\end{abstract}

Keywords: cyberbullying, empathy, partial least square, school environment, self-esteem.

\section{APA SAJA YANG MEMBANGUN MODEL CYBERBULLYING SISWA SEKOLAH MENENGAH KEJURUAN}

\begin{abstract}
Abstrak: Cyberbullying mengacu pada serangkaian perilaku agresif yang dilakukan melalui media sosial dalam bentuk penghinaan berulang, mempermalukan, dan mengancam orang lain. Tujuan penelitian ini adalah untuk menganalisis model pengaruh empati, self-esteem, dan iklim sekolah terhadap cyberbullying pada siswa kejuruan. Populasi penelitian ini adalah seluruh siswa kelas XI siswa Sekolah Menengah Kejuruan X, Y, dan Z di Yogyakarta yang berjumlah 505 siswa. Sample dalam penelitian ini adalah 180 siswa yang dipilih dari populasi dengan menggunakan teknik cluster random sampling. Data dikumpulkan menggunakan skala cyberbullying, skala empati, skala self-esteem, dan skala iklim sekolah. Analisis data dilakukan dengan pengujian outer model dan inner model dengan Structural Equation Model (SEM) melalui program Smart Partial Least Square 3.2.8. Hasil penelitian ini adalah terbentuknya model pengaruh empati, self-esteem, iklim sekolah terhadap cyberbullying berdasarkan data empirik. Hasil dari penelitian ini menunjukkan bahwa terdapat pengaruh negatif yang sangat signifikan antara empati dan iklim sekolah terhadap cyberbullying. Sebaliknya, tidak terdapat pengaruh self-esteem terhadap cyberbullying pada siswa.
\end{abstract}

Kata Kunci: cyberbullying, empati, partial least square, iklim sekolah, self-esteem.

\section{INTRODUCTION}

The advanced development of information and technology in the past decade has significantly impacted the world-Indonesia included. Humans are familiar with the state of the art technologies, for example, smartphones that are equipped with numerous features and internet connection. One of the implications of this is the increasing use of the internet and, more specifically, the frequent use of social media. A survey conducted by the Association for Indonesian Internet Providers (APJII) (2019) found that $54.68 \%$ or 132.26 million Indonesians are using the internet. Most of these users are within the 19-34 age group (49.52\%), while the most active users of the internet belong to the 13-18 age group reach $75.50 \%$.

Cyberbullying refers to a range of aggressive behaviors that are performed using social media and can take the form of repeated insults, shaming, and threats to other people (Tokunaga, 2010). Savage \& Tokunaga (2017) 
further elaborate on the characteristics of cyberbullying. First of all, it involves the use of communication technology, for example, instant messaging, text messaging, and cellphone use. Second, the perpetrator of cyberbullying takes advantage of communication technology to threaten or endanger another person. The perpetrator may send messages that are physically or psychologically threatening, ostracizing, or it may contain negative rumors, misinformation, or encouragement of others to engage in bullying. Third, cyberbullying is done purposely and intentionally to tease or joke around with another person. Fourth, cyberbullying is done repeatedly.

Research has shown that one of the negative impacts of the advance of the internet is cyber bullying (Peled, 2019; Macaulay, Betts, Stiller, \& Kellezi, 2018). Cyberbullying is viewed as a problem that has negative implications toward the social environment, and its negative impact affects both the perpetrator and the victim (Horner, Asher, \& Fireman, 2015). The increase of cyberbullying among students corresponds to the increase in internet and social media use.

Cyberbullying Research Center in the United States (2016) with 5705 participants aged 12 to 17 reported that approximately 648 participants have participated in cyberbullying (Patchin \& Hinduja, 2016). Around 405 participants confessed that the form of cyberbullying was in giving negative comments toward another person. Furthermore, around 456 participants reported that in the past 30 days, they have engaged in other forms of cyberbullying, either twice or more. Research from UNICEF (2016), found that $50 \%$ of 41 students in Indonesia aged 13-15, have experienced cyberbullying. In this study, cyberbullying took the form of publishing other people's data, stalking (stalking on the web followed by actual stalking in reality), and revenge in the form of spreading photos or videos to intimidate or blackmail another person.

Vocational high schools are the focus of this research. The problems in Vocational High Schools are very interesting and varied. Currently, from year to year, data shows the number of Vocational High School students is increasing. What is unique about Vocational High Schools is that they are predominantly male students. It is very rare for female students to attend vocational high schools. The large number of Vocational High School students, high juvenile delinquency which is dominated by male students, the backgrounds of Vocational High School students vary such as the level of education of parents, the economic level of parents, and social backgrounds. In addition, many people make Vocational High Schools the last choice in choosing a school. These things cause the opportunity for cyberbullying to be greater in the Vocational High School environment.

Perpetrators of cyberbullying perceive that their actions are just for fun (Rahayu, 2012). However, research has shown that cyberbullying may lead to adverse effects, for example, declines in academic performance, development of social and emotional problems (Peled, 2019), and cause low self-esteem (Webber \& Ovedovitz, 2018; Palermiti, Servidio, Bartolo, \& Costabile, 2016). Also, cyberbullying may motivate students to avoid school (Payne \& Hutzell, 2017) and disrupt concentration and academic performance (Akcil, 2018). Research has shown that cyberbullying can cause anxiety, stress and depression (Akcil, 2018; Navarro, 2016). It could also lead to juvenile delinquency such as alcohol abuse, substance abuse, and deviant sexual behaviors (Graham \& Wood, 2019; Webber \& Ovedovitz, 2018; Selkie, Kota, Chan, \& Moreno, 2015). Cyberbullying can lead to thoughts related to suicidal intentions (Ghadampour, Shafiei, \& Heidarirad, 2017).

Many factors contribute to cyberbullying, one of which, is the low empathy (Willard, 2005). Barlińska, Szuster, \& Winiewski (2015) show that empathy has an influence on cyberbullying. Empathy makes a person does not choose to engage in cyberbullying. Empathy refers to feeling what others feel, understanding another person's perspective, and creating a trusting relationship with other people. Empathy consists of several aspects namely: perspective taking, which refers to the tendency for a person to take another person's perspective spontaneously; fantasy, which is a person's ability to imaginatively feel and act in such a manner that represents an imaginative character in a book, film, and play which is read and watched; empathic concern, refers to feelings of care and sympathy oriented toward another person and concern for the misfortunes of other people; personal distress, refers to a 
person's anxieties and sadness in response to an unpleasant interpersonal experience.

One of the distinct characteristics of cyberbullying compared to traditional bullying is that the perpetrator's identity is concealed. The perpetrator may not be fully aware of how their actions may affect the victims. Furthermore, research has shown that perpetrators of cyberbullying have lower empathy compared to those who conduct bullying in person (Zych, Baldry, Farrington, \& Llorent, 2019; Brewer \& Kreslake, 2015; Steffgen \& Konig, 2009). The perpetrators have lower empathy in both affective and cognitive aspects and tend to intimidate those perceived as weak (Antoniadou \& Kokkinos, 2018).

Furthermore, Willard (2005) highlights another factor related to cyberbullying, namely, self-esteem. Research has shown that people with low self-esteem are more likely to engage in cyberbullying whether as a victim or as a perpetrator (Balakrishnan, 2018; Brewer \& Kreslake, 2015; Hinduja \& Patchin, 2010). Furthermore, cyberbullying has shown to make a person have lower self-esteem (Webber \& Ovedovitz, 2018; Palermiti et al., 2016). Selfesteem refers to a personal evaluation of the self as meaningful, capable, successful, and worthy. Self-esteem is the positive or negative evaluation of the self, made by an individual. Self-esteem is composed of some aspects namely: significance, which is the extent that a person views themselves as a having a meaningful presence in the environment; power, is a person's ability to influence and control other people and control one's self; virtue, refers to compliance towards moral and ethical values as well as the rules that exist in the society, and competence, which refers to success marked by high achievement.

Apart from self-esteem, the school environment also plays a role in affecting cyber-bullying. A reference study from Orpinas \& Horne (2006), Ferráns \& Selman (2014) suggest that there is an influence between the school environment and the school with the incidence of bullying. The school environment refers to the quality and characteristics of the school environment as well as the individual's experience of learning at this particular school (Hong, Espelage, \& Lee, 2018). Several dimensions characterize the school environment, namely: safety, referring to a student's perceived physical safety, and security in the socioemotional aspect which would make a student feel more comfortable at school to learn and can increase their academic achievements; relations, refers to the relationships between students at the school. Instruction and learning refer to the practical instruction and learning which includes the quality and creativity of the instructor; social and emotional learning, and ethics; professional development; and leadership abilities; and the final dimension is the institutional environment, referring to the physical environment of the school.

The school has an essential role in observing students' online activity, and they may have to implement interventions that are reinforced by a positive school environment (Schultze-Krumbholz, Schultze, Zagorscak, Wölfer, \& Scheithauer, 2016). When teenage students feel comfortable in school environments, negative behaviors like cyberbullying will not occur. Research has shown that positive school environments are protective factors against a range of negative behaviors such as substance abuse, aggression, including bullying and cyberbullying (Cardillo, 2013). Furthermore, Davis \& Koepke (2016) also found that a positive school environment protects teenagers from experiencing cyberbullying.

This research is expected to produce a novelty model, in the form of a tested and fit model that can contribute to overcoming cyberbullying problems. The novelty of this model involves the solution variables to be tested, namely the variable empathy, self-esteem, and school environment. In addition, the novelty of this research is the use of Structural Equation Modeling (SEM) with the Partial Least Squares (PLS) approach.

Based on the elaborations above and given the significance of cyberbullying among students, therefore the goal of the current study is to 1) design and test a theoretical model that describes the effect of empathy, self-esteem, school environment on cyberbullying, which has a good fit with the empirical data. 2) Test the effect of empathy on cyberbullying on students. 3 ) Test the effect of self-esteem on cyberbullying on students. 4) Test the effects of the school environment on student cyberbullying. 


\section{METHODS}

\section{Participants}

The population of this research were students of the Vocational School X, students from the Vocational School Y, and students from the Vocational School Z. This population consists of 505 students, and all of them were from Yogyakarta. The method of sampling in each school was using simple random sampling technique and 180 students were recruited for the research.

\section{Instruments}

The cyberbullying scale (Willard, 2005) was used in this research to measure cyberbullying. This scale consists of seven aspects: flaming, harassment, denigration, impersonation, outing and trickery, exclusion, and cyber-stalking. This scale uses the semantic differential model and consists of 35 items. Sample Statements from the Cyberbullying is presented in Table 1.
The instrument used to measure empathy in this research is based on the four dimensions from Davis (1983), namely perspective taking, fantasy, empathic concern, and personal distress. This scale was made by the researcher using the Likert format and consists of 24 items. An example of the item is "when I have a conflict with a friend, I try to understand their perspective before making a decision," "After watching a movie, I feel that I become one of the characters that I am watching," "I am easily moved by the things that I see" and "In an emergency, I feel worried."

Self-esteem scale by Coopersmith (1967) was used to measure self-esteem and consists of the aspects of significance, power, virtue, and competence. This scale used the Likert format and consisted of 24 items. An example of the item is "I enjoy receiving compliments," "I can do many things like other people," "I always try to stay positive towards myself," and "I feel doubtful in working on my tasks."

Table 1. Sample Statements from the Cyberbullying

\begin{tabular}{|c|c|c|c|c|c|}
\hline \multicolumn{6}{|c|}{ When I use social media, I use words that are ...... } \\
\hline Frank & 1 & 2 & 3 & 4 & Offensive \\
\hline Not provocative & 1 & 2 & 3 & 4 & Provocative \\
\hline \multicolumn{6}{|c|}{ When I send messages, text, and images on social media, I use words that are ... other peopl } \\
\hline Not disturbing & 1 & 2 & 3 & 4 & Disturbing \\
\hline Complimenting & 1 & 2 & 3 & 4 & Insulting \\
\hline \multicolumn{6}{|c|}{ When using social media, I ... of other people } \\
\hline Maintain the reputation & 1 & 2 & 3 & 4 & Destroy the reputation \\
\hline Spread positive news & 1 & 2 & 3 & 4 & Spread negative news \\
\hline \multicolumn{6}{|c|}{ When using social media, I.... another person's account } \\
\hline Don't impersonate & 1 & 2 & 3 & 4 & Impersonate \\
\hline Don't hack & 1 & 2 & 3 & 4 & Hack \\
\hline \multicolumn{6}{|c|}{ When receiving news about a friend on social media, I ..... } \\
\hline Don't look & 1 & 2 & 3 & 4 & Look \\
\hline Save & 1 & 2 & 3 & 4 & Share \\
\hline \multicolumn{6}{|c|}{ When having a problem with a friend on social media, I ...... } \\
\hline Don't ostracize & 1 & 2 & 3 & 4 & Ostracize \\
\hline Don't block & 1 & 2 & 3 & 4 & Block \\
\hline \multicolumn{6}{|c|}{ When sending a message in social media, I... other people } \\
\hline Don't Scare & 1 & 2 & 3 & 4 & Scare \\
\hline Support & 1 & 2 & 3 & 4 & Intimidate \\
\hline
\end{tabular}

The school environment scale developed by Cohen, McCabe, Michelli, \& Pickeral (2009) was used to measure the school environment. This scale consists of four aspects: safety, relationship, instruction and learning, and institutional environment. This scale uses a Likert format and consists of 24 items. Each aspect consists of 6 items. A sample item is " $I$ feel physically secure or verbally secure when in the school environment," "My teachers use the learning method that is easy to use to understand the material," and "My parents and school representatives communicate about my school activities," and "The classroom is organized well and looks neat and lovely." 


\section{Validity and Reliability}

Tests of the instruments' validity and reliability used SEM-PLS. Measurement of the outer model is conducted to evaluate the model's validity and reliability (Ghozali \& Latan, 2015). Tests of construct validity use PLS, which consists of two tests of validity, namely convergent validity, and discriminant validity. Tests of convergent validity are done to measure correlations between the measures (manifest variables) of a construct. Convergent validity can be evaluated based on the loading factors of each indicator. The loading factor value used to state whether a construct is valid or not is $>.4$ (Hair, Hult, Ringle, \& Sarstedt, 2016) and the Average Variance Extracted (AVE) value > .5 (Ghozali \& Latan, 2015). Discriminant validity is evaluated based on comparing the root Average Variance Extracted (AVE) on each construct with the root Average Variance Extracted (AVE) on other constructs or variables. Good discriminant validity is indicated by the correlation value of the root Average Variance Extracted (AVE) of a construct that is greater than the correlation with the root Average Variance Extracted (AVE) on other constructs (Ghozali \& Latan, 2015).

Tests of reliability were conducted using SEM-PLS, which can be done in two ways, namely by using composite reliability of Cronbach Alpha. Constructs are said to have excellent reliability when the Cronbach value is $>$.6 (Ghozali \& Latan, 2015), and the value of the composite reliability $>.7$ (Hair et al., 2016).

\section{Data Analysis}

Hypothesis tests were done using tests of the inner model, which can be done in three ways, namely observing the coefficient of determination $\left(R^{2}\right)$, predictive relevance $\left(Q^{2}\right)$, and the $G o F$ index. The effects between variables are tested using predictive relevance, namely using the bootstrapping resampling method developed by Geisser.

\section{FINDINGS AND DISCUSSION Findings}

The analyses were conducted using the SMART PLS 3.2.8 program to test the outer and inner model.

\section{Tests of the Outer Model}

Analysis of the outer model comprised of convergent validity, discriminant validity, composite reliability, and Cronbach alpha. Tests of the outer model are presented in Figure 1.

\section{Tests of Convergent Validity}

Convergent validity was established based on factor loadings $>.5$ and the value of Average Variance Extracted (AVE) $(>.5)$. The range of factor loadings for each variable is presented in Table 2.

Table 2. Factor Loadings

\begin{tabular}{lll}
\hline Variable & $\begin{array}{l}\text { The Score } \\
\text { Ranges } \\
\text { from Factor } \\
\text { Loadings }\end{array}$ & Description \\
\hline Cyberbullying & $.589-.893$ & Valid \\
Empathy & $.576-.885$ & Valid \\
Self esteem & $.569-.872$ & Valid \\
School environment $.586-.868$ & Valid \\
\hline
\end{tabular}

Based on Table 2, the results of the analyses showed that the factor loadings for each item had met the criteria of $>.5$, which means that all items are valid. The cyberbullying scale consists of 35 items, and 33 of them were valid. The empathy scale consists of 24 items, and 18 items were found to be valid. The self-esteem scale consists of 24 items, and 18 items were found to be valid. The school environment scale consists of 24 items, and 17 items were found to be valid.

Therefore, the root Average Variance Extracted (AVE) for each variable has met the criteria of discriminant validity (AVE $>.5$ ). The AVE for each variable is presented in Table 3.

Table 3. Average Variance Extracted (AVE)

\begin{tabular}{lcl}
\hline Variable & $\begin{array}{c}\text { Average } \\
\text { Variance } \\
\text { Extracted } \\
\text { (AVE) }\end{array}$ & Description \\
\hline Cyberbullying & .507 & Valid \\
Emphaty & .503 & Valid \\
Self esteem & .548 & Valid \\
School environment & .572 & Valid \\
\hline
\end{tabular}

Based on Table 3, cyberbullying, empathy, and self-esteem and school environment have an AVE $>.5$, and therefore the research variables have met the criteria of convergent validity. 


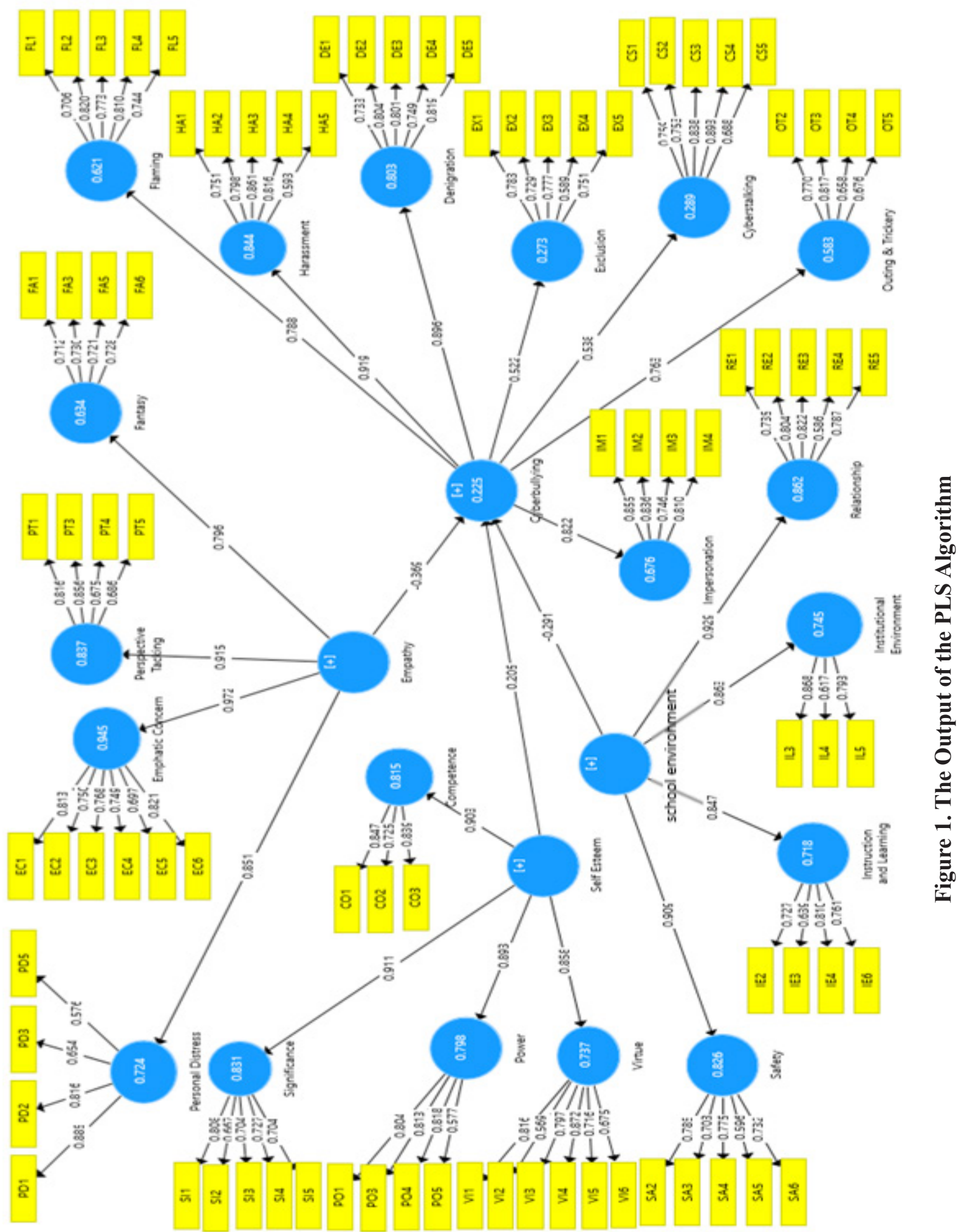




\section{Tests of Discriminant Validity}

Discriminant validity can be observed by comparing the values of the root AVE with the AVE of other variables. A scale is said to be valid when the correlation of the root AVE of particular variables is higher than the correlation root AVE of the other variables (Hair et al., 2016). The root AVE is presented in Table 4.
Based on Table 4, cyberbullying, empathy, self-esteem and school environment has met the criteria of discriminant validity since the correlation of a specific variable is higher compared to the correlation between the other construct variables. Therefore, we can conclude that all variables in this research have met the criteria of discriminant validity.

Table 4. Discriminant Validity

\begin{tabular}{lcccc}
\hline & Cyberbullying & Empathy & Self Esteem & School Environment \\
\hline Cyberbullying & .710 & -.383 & -.182 & -.417 \\
Empathy & -.383 & .740 & .733 & .565 \\
Self esteem & -.182 & .733 & .756 & .401 \\
School environment & -.417 & .565 & .461 & .712 \\
\hline
\end{tabular}

\section{Reliability}

The construct reliability can be shown from the composite reliability and Cronbach Alpha. A construct is said to be reliable when the composite reliability and Cronbach alpha $>$ .7 (Hair et al., 2016). Also, according to Cooper, when the root AVE meets the criteria of $>.5$, this supports reliability because it meets the criteria of construct validity. Therefore the construct is said to be both valid and reliable (Jogiyanto, 2011). The value of the composite reliability and Cronbach in this study is presented in Table 5.

Based on Table 5, the reliability of cyberbullying, empathy, and self-esteem and school environment met the criteria of composite reliability $>.7$ and Cronbach alpha $>.7$, so it can be concluded that all constructs or variables in this research have met the criteria for construct reliability.

\section{Tests of the Inner Model}

Tests of the inner model aim to ensure that the structural model is robust and accurate. The results of the test of the inner model are presented in Table 6 and Figure 2.

Table 5. Reliability at the Final Stage

\begin{tabular}{lccl}
\hline Variable & Composite Reliability & Cronbach Alpha & Description \\
\hline Cyberbullying & .911 & .925 & Reliable \\
Empathy & .923 & .934 & Reliable \\
Self esteem & .897 & .916 & Reliable \\
School environment & .892 & .914 & Reliable \\
\hline
\end{tabular}

Table 6. Results of Analysis and $R^{2}, Q^{2}$ Values

\begin{tabular}{|c|c|c|c|}
\hline Criteria & Rule of Thumb & Values & Description \\
\hline $\begin{array}{l}\text { Coefficient of } \\
\text { determination } \\
\left(R^{2}\right)\end{array}$ & $\begin{array}{l}.67 \text { (strong), .33 (moderate), and } .19 \\
\text { (weak) (Ghozali \& Latan, 2015) }\end{array}$ & .225 & $\begin{array}{l}\text { Effect of exogenous } \\
\text { variables on } \\
\text { endogenous variables }\end{array}$ \\
\hline $\begin{array}{l}\text { Predictive } \\
\text { relevance }\left(Q^{2}\right)\end{array}$ & $\begin{array}{l}Q^{2}>0 \text { (good predictive relevance) } \\
Q^{2}<0 \text { (Lack of model predictive } \\
\text { relevance) }\end{array}$ & .111 & $\begin{array}{l}\text { Good } \\
\text { relevance }\end{array}$ \\
\hline Effect size $\left(f^{2}\right)$ & $\begin{array}{l}\text { Effect size }\left(f^{2}\right)>.015 \text { indicates good effect } \\
\text { size }\left(f^{2}\right) \text { from exogenous variables toward } \\
\text { endogenous variables (Ohen, Stepen, \& } \\
\text { Ronald, 1998) }\end{array}$ & $\begin{array}{l}\text { - Empathy toward } \\
\text { cyberbullying: .066 } \\
\text { - Self-Esteem toward } \\
\text { cyberbullying: } .025 \\
\text { - School environment } \\
\text { toward cyberbullying: } 074\end{array}$ & $\begin{array}{l}\text { Effect of exogenous } \\
\text { variables on } \\
\text { endogenous variables }\end{array}$ \\
\hline $\begin{array}{l}\text { Goodness of } \\
\text { fit }(G o F)\end{array}$ & $\begin{array}{l}\text { Criteria of } G o F \text { namely .10 ( } G o F \text { weak), } \\
.25 \text { (GoF moderate), and } .36 \text { ( } G o F \text { strong) } \\
\text { (Ghozali \& Latan, 2015) }\end{array}$ & .346 & Moderate $G o F$ \\
\hline
\end{tabular}




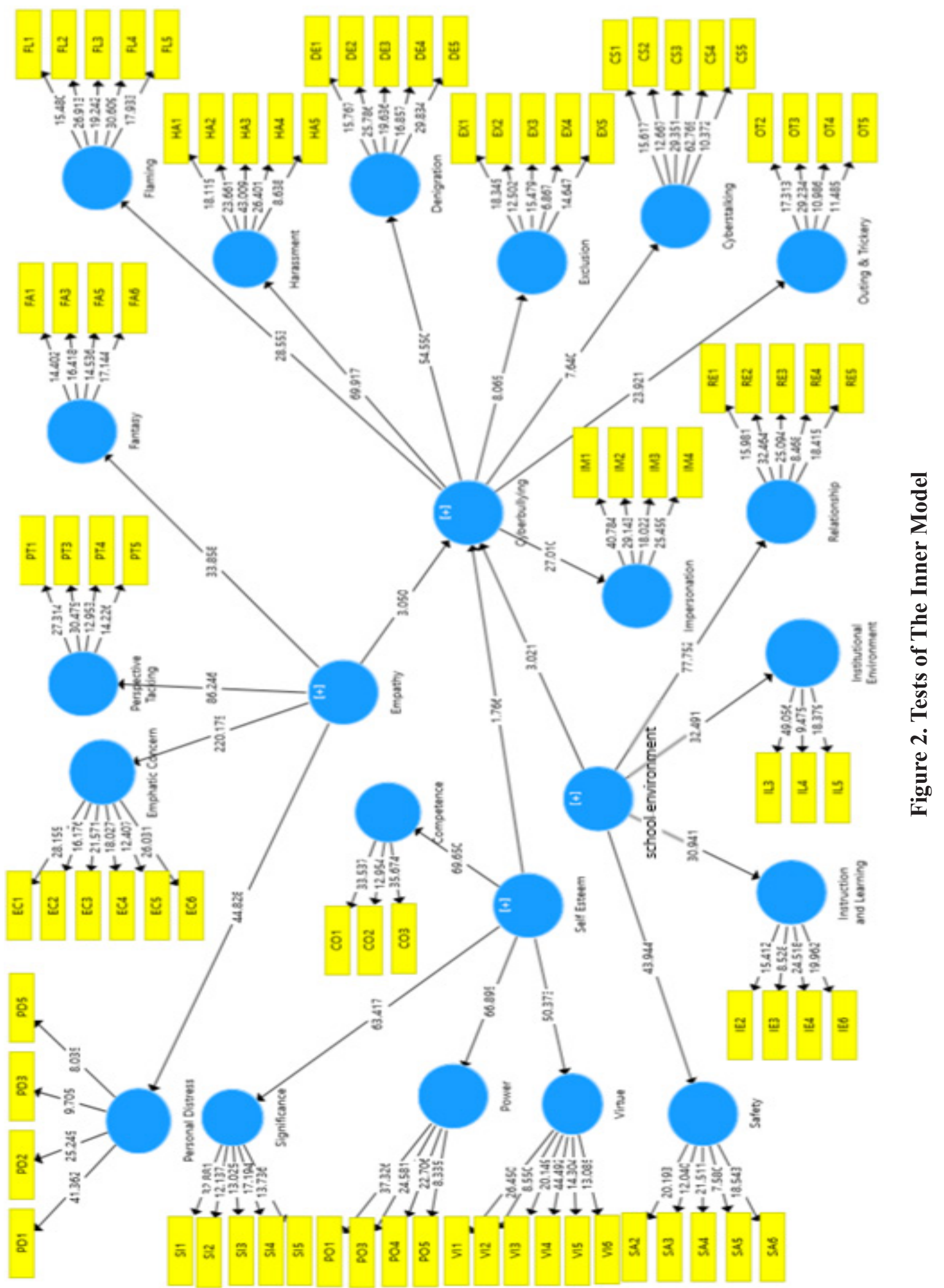


Based on the test of the inner model in Figure 2, the effect of empathy, self-esteem, and school environment toward cyberbullying fits with the empirical data well. The Goodness of Fit (GoF) value of .346 ( $>.25$, GoF moderate) means that the overall structural model which is the combined performance of the measurement model and the structural model is declared valid.

\section{Test of Hypothesis}

After creating the model and obtaining a good model fit, therefore, we need to observe the effects between variables. Tests of the hypothesis were done by observing the probability value namely, $p<.05$ and observe $t$-statistics, namely $t$-statistics $>1.96$ that indicates that the hypothesis is accepted. The analyses of $p$-values and $t$-statistics are presented in Table 7 .
Based on the hypothesis tests on Table 7, therefore the results of the hypotheses tests are as follows. The results of the hypothesis tests are based on $R^{2}=.225, Q^{2}=.111$, and $G o F=$ .346. Therefore the hypothesis is accepted. Therefore the model which predicts the effects of empathy, self-esteem, school environment on cyberbullying among students has a good fit with the empirical data. The tests of the second hypotheses showed that it was accepted, based on the $p$-value .002 and $t$-statistic 3.057 with an original sample value of -.369. Therefore this shows a significant negative effect between empathy and cyberbullying. The higher the empathy, therefore, the lower the cyberbullying among students, and conversely, the lower the students' empathy, the higher the cyberbullying among students.

Table 7. Tests of Hypotheses

\begin{tabular}{lccccll}
\hline Effects of Variable & $\begin{array}{c}\text { Original } \\
\text { Sample }\end{array}$ & $\boldsymbol{t}$-Statistics & $\boldsymbol{p}$-Value & Criteria & Description \\
\hline Cyberbullying-Empathy & -.369 & 3.055 & .002 & $p<.05$ & $\begin{array}{l}\text { Negative effect and } \\
\text { very significant }\end{array}$ \\
Cyberbullying-Self-esteem & .205 & 1.766 & .069 & $p>.05$ & $\begin{array}{l}\text { Not significant } \\
\text { Cyberbullying-School environment }\end{array}$ \\
& -.291 & 3.021 & .004 & $p<.05$ & $\begin{array}{l}\text { Negative effect and } \\
\text { very significant }\end{array}$ \\
\hline
\end{tabular}

Analysis of the third hypothesis reveals that the hypothesis is rejected. This conclusion is made based on the $p$-value $.069, t$-statistic 1.822 , and original sample .205. This indicates that there was no effect of self-esteem on cyberbullying among students. Furthermore, the results of the fourth hypothesis showed that the hypothesis was accepted. The $p$-value .004 and $t$-statistic 2.876 with an original sample -.291 indicates that the school environment has a negative influence on cyberbullying. The better the school environment is, the lower the cyberbullying, and conversely, the poorer the school environment, the higher the cyberbullying among students.

\section{Discussion}

A large body of research exists on the topic of cyberbullying. Initially, this research focused on defining cyberbullying, and particularly on the prevalence of cyberbullying among Junior High School Students (Kowalski, Limber, \& McCord, 2019). However, research then expanded to a broader sample which included different age groups, for example, elementary school students, junior high school students, university students and even adults (particularly in the workplace) (Barlett \& Chamberlin, 2017; Ševčíková \& Šmahel, 2009).

In line with the advances of the era, more people are using the internet to play games and use social media platforms. In line with this, many people are unaware that they may be engaging in cyberbullying; however, they do not intend to engage in other forms of intimidation (Kowalski, Limber, \& Agatston, 2012). Furthermore, the amount of time a person spends online correlates with their involvement in cyber intimidation (Çelik, Atak, \& Erguzen, 2012). Therefore, when all people in this demographic age spend their time online using technological devices, there is a higher likelihood that the prevalence of cyberbullying will increase.

Research has documented the factors that influence cyberbullying, which include traditional bullying (Rahayu, 2012), personality characteristics, perceptions toward school 
(Petrie, 2014), and a reduction of morals, for example, low empathy (Brewer \& Kreslake, 2015). This research uses empathy, self-esteem, and school environment as the exogenous variable, with the school environment as the setting and the students as the subjects.

Based on the results of the analysis, three of the four hypotheses were accepted, and one hypothesis was rejected. The first hypothesis was accepted with values of the coefficient of determination $\left(R^{2}\right)$, Predictive Relevance $\left(Q^{2}\right)$, and goodness of fit index $(G o F)$, which all met the criteria of a model with a good fit. This indicates that empathy, self-esteem, school environment among students of vocational high school affect cyberbullying. The model in the current research is novel because it simultaneously tests the relationships between variables empathy, selfesteem, and school environment. Other models have been tested, for example, cyberbullying being predicted by self-efficacy, which is affected by memories of warmth and security. Cyberbullying itself was affected by becoming a victim of cyberbullying (Bingöl, 2018). Other research has shown that being a victim of cyberbullying negatively associates with lower social self-efficacy. At the same time, social self-efficacy negatively associates with work satisfaction and also mediates the relationship between cyberbullying and work satisfaction (Jones, 2019). Furthermore, research from Shadmanfaat, Howell, Muniz, Cochran, Kabiri, \& Richardson (2018) found that individuals with low self-control tend to be involved in cyberbullying.

This research is also considered novel due to the analysis techniques used. This research uses Structural Equation Model (SEM) through the Partial Least Squares program, while past research on cyberbullying uses SEM using the Lisrel program (Menesini, Nocentini, \& Comodeca, 2011; Çetin, Eroğlu, Peker, Akbaba, \& Pepsoy, 2012; Hamer \& Konijn, 2015; DelRey, Lazuras, Casas, Barkoukis, Ortega-Ruiz, \& Tsorbatzoudis, 2016), with Amos (Casas, Del Rey, \& Ortega-Ruiz, 2013), and regression analyses using IBM SPSS (Ghamrawi, Ghamrawi, \& Shal, 2016; Dilmaç, 2017; Cosma, Walsh, Chester, Callaghan, Molcho, Craig, \& Pickett, 2020).

The second hypothesis was accepted, which showed that there was a negative effect of empathy on cyberbullying among students. Therefore this means that one of the factors that contribute to cyberbullying is empathy. $36.9 \%$ of the variance of cyberbullying can be attributed to empathy, meaning the higher the score of empathy means the students have higher empathy. In contrast, low scores show that the students have low empathy. Therefore we can conclude that the higher empathy, the lower likelihood a person engages in bullying directly or online (cyberbullying).

There was an effect of empathy on cyberbullying, which is supported by research from Pfetsch (2017) that showed that a person's abilities of empathy would affect their tendency to intimidate another person either directly or online. Furthermore, research from Barlinska, Szuster, and Winiewski (2015) showed that empathy makes a person not choose to engage in cyberbullying.

Other research by Del-Rey et al. (2016) showed that empathy consists of cognitive and affective components, which is essential in traditional bullying, however bullying in the cyber world, apart from gender, age and nationality can also affect cyberbullying. Research from Brewer \& Kreslake (2015) also showed that empathy affects a person to engage in cyberbullying. Furthermore, research from Topcu \& Erdur-Barker (2012) showed that affective empathy or cognitive empathy could be used as a mediator to prevent aggression in the cyber world. Furthermore, Schultze-Krumbholz, Schultze, Zagorscak, Wölfer, and Scheithauer (2016) researched the effects of empathy training on cyber intimidation, and the results showed that increasing empathy makes people less likely to engage in cyberbullying.

The effects of empathy on cyberbullying on students were caused by higher empathy among students, which made them have more tolerance and concern towards people's needs of others and helps other people who are dealing with difficulties (Borba, 2002). Students who can feel the difficulties of other people would not spread negative rumors about other people on the internet to damage a person's right name or reputation. Students who have abilities to express empathy tend to be able to take the perspective of other people easily. Students with higher empathy also can imitate the feelings and actions of imaginary characters. This process 
would induce an emotional reaction and produce helping behaviors toward the victim, which would lead teenagers to be more understanding of the feelings of victims and teenagers and refrain from engaging in online aggression.

The third hypothesis was rejected, which showed that there was no effect of self-esteem on cyberbullying among students. This meant that there was no effect of significance, power, virtue, and competence toward cyberbullying. Additionally, this implies that lower selfesteem makes a person have higher tendencies to engage in cyberbullying. The results are different from past research. For example, Fan, Chu, Zhang, \& Zhou (2016) showed that selfesteem mediated narcissism and cyberbullying, which makes students have high self-esteem and also avoid cyberbullying behaviors. Other research has shown that self-esteem does not affect cyberbullying (Balakrishnan, 2018; You, Lee, \& Kim, 2016). Other research has shown that self-esteem has a weak relationship with cyberbullying.

The last hypothesis was accepted, namely that there was a negative effect of the school environment on cyberbullying among students. This meant that one of the factors that contribute to cyberbullying is the school environment. The variance of cyberbullying explained by the school environment is $29.1 \%$, meaning that the higher the score indicated a better school environment and a lower score indicated a poor school environment. Therefore it can be concluded that the better the school environment, therefore the lower likelihood that a student would engage in cyberbullying directly or online (cyberbullying).

The existence of the effect of the school environment on cyberbullying is supported by research from Bayar \& Ucanok (2012), who suggested that the school environment affects aggression in the cyber world. Other research has shown that the factors that affect bullying are the same as those that affect cyberbullying, both of which include school environment (Casas et al., 2013). The results of the research are in line with research form Narpaduhita \& Suminar (2014), who found a negative relationship between positive perceptions of the school environment and cyberbullying. This indicates that a better school environment would lead to lower cyberbullying. Conversely, when the perception of the school environment is terrible, therefore this would be associated with higher cyberbullying, which means they would be more vulnerable to cyberbullying.

The school is an external environment that is close to the students. School environment affected the levels of aggression. Whereby a positive school environment indicated a safe school for the physical and psychological development of the students. A positive school environment can reduce aggression. Schools can also be a conducive place when they provide a sense of security, comfort, are perceived as valuable and beneficial for the students. This favorable climate can prevent or reduce the likelihood of aggressive behaviors like cyberbullying to occur. Therefore, we can conclude that the better the school environment, therefore, the lower chances that a child would engage in bullying either directly or online (cyberbullying).

Schools can take a role in overcoming cyberbullying problems by implementing the cyberbullying treatment model from this study. The school can pay attention to important factors that can reduce the level of cyberbullying in students, especially the factors of empathy and the school environment. The school can train students to be able to empathize with their peers, train feelings of caring and sympathy which are oriented towards others and concern for the suffering experienced by others. In addition, it creates a safe and comfortable school environment so that every student in school feels calm, there are clear rules regarding violence in schools and the existence of teaching conflict resolution and attitudes to cyberbullying behavior, creating good relationships between students and teachers and students and their peers. The school, through supportive teachers, can provide the right response in dealing with student creativity so that students can develop creativity and innovation in the real world, so that students learn actively and collaboratively and can encourage student interaction.

\section{CONCLUSION}

Based on the results of the analyses, the model of cyberbullying had a good fit, and this was following the empirical data. The first hypothesis showed that the model using empathy, self-esteem, and school environment in affecting cyberbullying had a good fit. The 
second hypothesis has shown a significant result, namely an adverse effect of empathy on cyberbullying, which explained $36.9 \%$ of the variance on cyberbullying. This indicates that the higher the empathy, the lower the cyberbullying on students. Conversely, the lower the empathy, the higher the cyberbullying.

The third hypothesis showed no significant results. Namely, the effect of self-esteem toward cyberbullying was not supported by the data. This indicates that the lower the self-esteem, the higher the cyberbullying among students. The fourth hypothesis showed a significant result, namely that there was a negative effect of the school environment on cyberbullying with a $29.1 \%$ variance explained by the model. This indicates that the better the school environment, the lower the cyberbullying among students, and conversely, a poor school environment would lead to more cyberbullying among students. Recommendations to the school that cyberbullying models are valid, therefore this model can be used as a reference for resolving the problems of cyberbullying at Vocational High School students with attention to the factors that proved to influence

\section{ACKNOWLEDGMENTS}

The authors wish to thank the Ministry of Research and Technology/National Research and Innovation Agency, Republic of Indonesia (RISTEK-BRIN) for providing support and funding for the completion of this research.

\section{REFERENCES}

Akcil, S. (2018). Cyberbullying-victimization, acculturativestress, and depression among international college students (Doctoral dissertation, Kent State University). https://etd.ohiolink.edu/apexprod/rws etd/send file/send?accession=kent 15297 12251699618\&disposition=inline.

Antoniadou, N., \& Kokkinos, C. M. (2018). Empathy in traditional and cyber bullying/victimization involvement from early to middle adolescence: A cross sectional study. Journal of Educational and Developmental Psychology, 8(1), 153-161. https://doi.org/10.5539/jedp. v8n1p153.
APJII (Association for Indonesian Internet Providers). (2019). Internet survey reports APJII 2019 -2020. https://apjii. or.id/survei2019x.

Balakrishnan, V. (2018). Actions, emotional reactions and cyberbullying-from the lens of bullies, victims, bully-victims and bystanders among Malaysian young adults. Telematics and Informatics, 35(5), 1190-1200. https://doi.org/10.1016/j. tele.2018.02.002.

Barlett, C. P., \& Chamberlin, K. (2017). Examining cyberbullying across the lifespan. Computers in Human Behavior, 71, 444-449. https://doi.org/10.1016/j. chb.2017.02.009.

Barlińska, J., Szuster, A., \& Winiewski, M. (2015). The role of short-and long-term cognitive empathy activation in preventing cyberbystander reinforcing cyberbullying behavior. Cyberpsychology, Behavior, and Social Networking, 18(4), 241-244. https://doi.org/10.1089/cyber.2014.0412.

Bayar, Y., \& Ucanok, Z. (2012). School social climate and generalized peer perception in traditional and cyberbullying status. Educational Sciences: Theory \& Practice, 12(4), 2352-2358. http://oldsite.estp.com. tr/en/makale.asp? $\mathrm{ID}=720$ \&act=detay.

Bingöl, T. Y. (2018). The predictive role of selfefficacy, gender, and cyber victimization on cyber bullying in adolescents. Universal Journal of Educational Research, 6(11), 2478-2483. https://doi.org/10.13189/ ujer.2018.061111.

Borba, M. (2002). Building moral intelligence: The seven essential virtues that teach kids to do the right thing. New York, NY: John Wiley \& Sons.

Brewer, G., \& Kerslake, J. (2015). Cyberbullying, self-esteem, empathy and loneliness. Computers in Human Behavior, 48, 255-260. https://doi.org/10.1016/j. chb.2015.01.073. 
Cardillo, R. (2013). School climate and youth development. New York, NY: National School Climate Center.

Casas, J. A., Del Rey, R., \& Ortega-Ruiz, R. (2013). Bullying and cyberbullying: Convergent and divergent predictor variables. Computers in Human Behavior, 29(3), 580-587. https://doi. org/10.1016/j.chb.2012.11.015.

Çelik, S., Atak, H., \& Erguzen, A. (2012). The effect of personality on cyberbullying among university students in Turkey. Eurasian Journal of Educational Research, (49), 129-150. http://ejer.com.tr/en/ archives/2012-fall-issue-49/the-effectof-personality-on-cyberbullying-amonguniversity-students-in-turkey-2715.

Çetin, B., Eroğlu, Y., Peker, A., Akbaba, S., \& Pepsoy, S. (2012). The investigation of relationship among relationalinterdependent self-construal, cyberbullying, and psychological disharmony in adolescents: An investigation of structural equation modelling. Educational Sciences: Theory and Practice, 12(2), 646-653. http://oldsite.estp.com.tr/en/makale. asp?ID $=637 \&$ act $=$ detay.

Cohen, J., McCabe, E. M., Michelli, N. M., \& Pickeral, P. (2009). School climate: Research, policy, practice, and teacher education. Teachers College Record Columbia University, 111(1), 180-213. https://www.tcrecord.org/content. asp? contentid $=15220$.

Coopersmith, S. (1967). The antecedents of selfesteem. San Francisco, CA: Freeman and Company.

Cosma, A., Walsh, S. D., Chester, K. L., Callaghan, M., Molcho, M., Craig, W., \& Pickett, W. (2020). Bullying victimization: Time trends and the overlap between traditional and cyberbullying across countries in Europe and North America. International Journal of Public Health, 65(1), 75-85. https://doi.org/10.1007/ s00038-019-01320-2.
Davis, K., \& Koepke, L. (2016). Risk and protective factors associated with cyberbullying: Are relationships or rules more protective? Learning, Media and Technology, 41(4), 521-545. https://doi.or g/10.1080/17439884.2014.994219.

Davis, M. H. (1983). Measuring individual differences in emphaty: Evidence for a multidimensional approach. Journal of Personality and Social Psychology, 44(1), 113-126. https://doi.org/10.1037/00223514.44.1.113.

Del-Rey, R., Lazuras, L., Casas, J. A., Barkoukis, V., Ortega-Ruiz, R., \& Tsorbatzoudis, H. (2016). Does empathy predict cyberbullying perpetration, and how do age, gender and nationality affect this relationship? Learning and Individual Differences, 45, 275-281. https://doi. org/10.1016/j.lindif.2015.11.021.

Dilmaç, B. (2017). The relationship between adolescents' levels of hopelessness and cyberbullying: The role of values. Educational Sciences: Theory and Practice, 17(4), 1119-1133. https://doi. org/10.12738/estp.2017.4.0610.

Fan, C. Y., Chu, X. W., Zhang, M., \& Zhou, Z. K. (2019). Are narcissists more likely to be involved in cyberbullying? Examining the mediating role of selfesteem. Journal of Interpersonal Violence, 34(15), 3127-3150. https://doi. org/10.1177\%2F0886260516666531.

Ferráns, S. D., \& Selman, R. L. (2014). How students' perceptions of the school climate influence their choice to upstand, bystand, or join perpetrators of bullying. Harvard Educational Review, 84(2), 162-187. $\quad$ https://doi.org/10.17763/ haer.84.2.h4883134101651mm.

Ghadampour, E., Shafiei, M., \& Heidarirad, H. (2017). Relationships among cyberbullying, psychological vulnerability and suicidal thoughts in female and male students. Journal of Research in Psychological Health, 11(3), 28-40. https://doi.org/10.29252/rph.11.3.28. 
Ghamrawi, N. A., Ghamrawi, N., \& Shal, T. (2016). Teachers' perception of cyberbullying in Lebanese public school. Open Journal of Leadership, 5(4), 95-109. $\quad$ https://doi.org/10.4236/ oj1.2016.54009.

Ghozali, I., \& Latan, H., (2015). Partial least squares: Konsep, teknik, dan aplikasi menggunakan program smart PLS. 3.0. [Partial least squares: Concepts, techniques and applications using smartPLS 3.0]. Semarang, Indonesia: Universitas Diponegoro.

Graham, R., \& Wood Jr, F. R. (2019). Associations between cyberbullying victimization and deviant health risk behaviors. The Social Science Journal, 56(2), 183-188. https:// doi.org/10.1016/j.soscij.2018.05.005.

Hair, J. F., Hult, G. T. M., Ringle, C., \& Sarstedt, M. (2016). A primer on partial least squares structural equation modeling (PLS-SEM). Thousand Oaks, CA: Sage publications.

Hamer, A. H., \& Konijn, E. A. (2015). Adolescents' media exposure may increase their cyberbullying behavior: A longitudinal study. Journal of Adolescent Health, 56(2), 203-208. https://doi. org/10.1016/j.jadohealth.2014.09.016.

Hinduja, S., \& Patchin, J. W. (2010). Bullying, cyberbullying, and suicide. Archives of Suicide Research, 14(3), 206-221. https:// doi.org/10.1080/13811118.2010.494133.

Hong, J. S., Espelage, D. L., \& Lee. J. M. (2018). School climate and bullying prevention programs. In H. Shapiro (Ed). The wiley handbook on violence in education: Forms, factors, and preventions. New York, NY: John Wiley \& Sons, pp. 359374.

Horner, S., Asher, Y., \& Fireman, G. D. (2015). The impact and response to electronic bullying and traditional bullying among adolescents. Computer in Humans Behaviors, 49, 288-295-221. https://doi. org/10.1016/j.chb.2015.03.007.
Jogiyanto, H. M. (2011). The concept and application of variant-based structural equation modeling in business research (in Indonesian). Yogyakarta, Indonesia: UPP STIM YKPN.

Jones, A. S. (2019). Cyberbullying and the workplace: An analysis of job satisfaction and social self-efficacy (Doctoral Dissertation, University of Iowa). https:// doi.org/10.17077/etd.zb1g-3v5s.

Kowalski, R. M., Limber, S. P., \& Agatston, P. W. (2012). Cyberbullying: Bullying in the digital age. New York, NY: John Wiley \& Sons.

Kowalski, R. M., Limber, S. P., \& McCord, A. (2019). A developmental approach to cyberbullying: Prevalence and protective factors. Aggression and Violent Behavior, 45, 20-32. https://doi.org/10.1016/j. avb.2018.02.009.

Macaulay, P. J., Betts, L. R., Stiller, J., \& Kellezi, B. (2018). Perceptions and responses towards cyberbullying: A systematic review of teachers in the education system. Aggression and violent behavior, 43, 1-12. https://doi.org/10.1016/j. avb.2018.08.004

Menesini, E., Nocentini, A., \& Camodeca, M. (2013). Morality, values, traditional bullying, and cyberbullying in adolescence. British Journal of Developmental Psychology, 31(1), 1-14. $\quad$ https://doi.org/10.1111/j.2044835X.2011.02066.X.

Narpaduhita, R. P. D., \& Suminar, D. R. (2014). Perbedaan perilaku cyberbullying ditinjau dari persepsi siswa terhadap iklim sekolah di smk negeri 8 surabaya. [The difference in cyberbullying behavior in terms of students' perceptions of the school climate at publict vocational high school 8 Surabaya]. Jurnal Psikologi Klinis dan Kesehatan Mental, 3(3), 146152. https://journal.unair.ac.id/JPKK@, perbedaan-perilaku-cyberbullyingditinjau-dari-persepsi-siswa-terhadapiklim-sekolah-di-smk-negeri-8-surabayaarticle-8853-media-51-category-10.html. 
Navarro, R. (2016). Gender issues and cyberbullying in children and adolescents: From gender differences to gender identity measures. In R. Navarro, S. Yubero, \& E. Larrañaga (Eds.). Cyberbullying across the globe: Gender, family, and mental health. New York, NY: Springer, Cham, pp. 35-61.

Orpinas, P., \& Horne, A. M. (2006). Bullying prevention: Creating a positive school climate and developing social competence. Washington, DC: American Psychological Association.

Palermiti, A. L., Servidio, R., Bartolo, M. G., \& Costabile, A. (2016). Cyberbullying and self-esteem: An Italian study. Computers in Human Behavior, 69, 136-141. https:// doi.org/10.1016/j.chb.2016.12.026.

Patchin, J. W., \& Hinduja, S. (2016). Bullying today: Bullet points and best practices. Thousand Oaks, CA: Corwin Press.

Payne,A.A.,\&Hutzell,K.L.(2017).Oldwine, new bottle? Comparing interpersonal bullying and cyberbullying victimization. Youth \& Society, 49(8), 1149-1178. https://doi. org/10.1177/0044118X15617401.

Peled, Y. (2019). Cyberbullying and its influence on academic, social, and emotional development of undergraduate students. Heliyon, 5(3), 1-22. https://doi. org/10.1016/j.heliyon.2019.e01393.

Petrie, K. (2014). The relationship beetwen school climate and student bullying. TEACH Journal of Christian Education, 8(1), 26-31. https://research. avondale.edu.au/cgi/viewcontent. cgi? article $=1237 \&$ context $=$ teach

Pfetsch, J. S. (2017). Empathic skills and cyberbullying: Relationship of different measures of empathy to cyberbullying in comparison to offline bullying among young adults. The Journal of Genetic Psychology, 178(1), 58-72. https://doi.org /10.1080/00221325.2016.1256155.

Rahayu, F. (2012). Cyberbullying Sebagai Dampak Negatif Penggunaan Teknologi
Informasi. [Cyberbullying as a negative impact on the use of information technology]. Jurnal Sistem Informasi, 8(1), 22-31. https://doi.org/10.21609/jsi. v8i1.321.

Savage, M. W., \& Tokunaga, R. S. (2017). Moving toward a theory: Testing an integrated model of cyberbullying perpetration, aggression, social skills, and Internet self-efficacy. Computers in Human Behavior, 71, 353-361. https:// doi.org/10.1016/j.chb.2017.02.016.

Schultze-Krumbholz, A., Schultze, M., Zagorscak, P., Wölfer, R., \& Scheithauer, H. (2016). Feeling cybervictims' painThe effect of empathy training on cyberbullying. Aggressive behavior, 42(2), 147-156. https://doi.org/10.1002/ ab. 21613 .

Selkie, E. M., Kota, R., Chan, Y. F., \& Moreno, M. (2015). Cyberbullying, depression, and problem alcohol use in female college students: A multisite study. Cyberpsychology, Behavior, and Social Networking, 18(2), 79-86. https:// doi.org/10.1089/cyber.2014.0371.

Ševčíková, A., \& Šmahel, D. (2009). Online harassment and cyberbullying in the Czech Republic: Comparison across age groups. Zeitschrift für Psychologie/ Journal of Psychology, 217(4), 227229 . $\quad$ https://doi.org/10.1027/00443409.217.4.227.

Shadmanfaat, S. M. S., Howell, C. J. M., Muniz, C. N., Cochran, J. K., Kabiri, S., \& Richardson, D. A. (2018). The predictive ability of self-control and differential association on sports fans' decision to engage in cyber bullying perpetration against rivals. International Journal of Cyber Criminology, 12(2), 362-375. https://www.cybercrimejournal.com/ admanfaatetalvol13issue1IJCC2018.pdf.

Steffgen, G., \& König, A. (2009, 13-15 May). Cyberbullying: The role of traditional bullying and empathy. In The Good, The Bad and The Challenging Conference Proceedings, 2, 1041-1047. 
Tokunaga, R. S. (2010). Following you home from school: A critical review and synthesis of research on cyberbullying victimization. Computers in Human Behavior, 26(3), 277-287. https://doi. org/10.1016/j.chb.2009.11.014.

Topcu, Ç., \& Erdur-Baker, Ö. (2012). Affective and cognitive empathy as mediators of gender differences in cyber and traditional bullying. School Psychology International, 33(5), 550-561. https://doi. org/10.1177/0143034312446882.

UNICEF. (2016). Ending the torment: Tackling bullying from the schoolyard to cyberspace. New York, NY: United Nations.

Webber, M. A., \& Ovedovitz, A. C. (2018). Cyberbullying among college students: A look at its prevalence at a US Catholic University. International Journal of
Educational Methodology, 4(2), 101-107. https://doi.org/10.12973/ijem.4.2.101.

Willard, N. (2005). Cyberbullying and cyberthreats. Washington, DC: US Departement of Education.

You, S., Lee, Y., \& Kim, E. (2016). Physical, social, and cyberbullying: Relationships with adolescents' psychosocial factors. Child Indicators Research, 9(3), 805823. https://doi.org/10.1007/s12187-0159338-y.

Zych, I., Baldry, A. C., Farrington, D. P., \& Llorent, V. J. (2019). Are children involved in cyberbullying low on empathy? A systematic review and meta-analysis of research on empathy versus different cyberbullying roles. Aggression and Violent Behavior, 45, 83-97. https://doi. org/10.1016/j.avb.2018.03.004. 